\title{
Newly Formed Bone in Mandible Decortication Experimental Model Using rhBMP-2 Evaluated by Densitometric Study
}

\author{
Tejido Óseo Neoformado en el Modelo Experimental de la \\ Retirada de la Cortical Ósea Mandibular Utilizando rhBMP-2
}

"João Paulo Mardegan Issa; "Rodrigo Tiossi; "Plauto Christopher Aranha Watanabe; "Selma Siéssere; "Simone Cecílio Hallak

ISSA, J. P. M.; TIOSSI, R., WATANABE, P. C. A.; SIÉSSERE, S.; REGALO, S. C. H. ; LOPES, R. A.; Di MATTEO, M. A. S.; IYOMASA, M. M. \& DEFINO, H. L. A.Newly formed bone in mandible decortication experimental model using rhBMP-2 evaluated by densitometric study. Int. J. Morphol., 26(1):83-88, 2008.

SUMMARY: The purpose of this study was to evaluate the newly formed bone, comparing two different carriers for rhBMP-2, using the decortication and nondecorticatication surgical technique in Wistar rat mandibles, evaluated by radiographic densitometry method. It was used fifty six animals according to specific treatment, which were sacrificed after 3 and 6 weeks after this. It was concluded that the decortication surgical technique was able to optimize the osteoinduction properties of the rhBMP-2, independently of the material carrier used and the period of time, according to radiographic densitometry technique.

KEY WORDS: Radiography; Densitometry; Mandible; rhBMP-2; Bone.

\section{INTRODUCTION}

Bone morphogenetic proteins (BMPs) stimulate regeneration of bone and cartilage (Jortikka et al., 1993a,b; Cook, 1999; Govender et al., 2002; Wozney, 2002; Cheng et al., 2003). The bone-healing properties of different recombinant and extracted BMPs have been studied using long bone defect models in rabbits (Hollinger et al., 1998; Kokubo et al., 2003), dogs (Tuominen et al., 2000), rats (Matsuo et al., 2003) and sheep (Gao et al., 1997). Favorable results in preclinical and clinical trials have also led to the regulatory approval of different commercial recombinant BMP products for some clinical purposes by government agencies (Matsuo et al.). Considering that there are about 30 BMPs known, products consisting of single recombinant BMPs cannot be regarded as being ideal. Also, our knowledge of their long-term effects and of how safe they are is still limited. BMPs occur as a mixture in living organisms, and native BMPs are also a mixture when extracted. Thus, studies aiming at safe and effective products from native BMPs are still needed.

Because the half-life of BMP is relatively short with respect to bone induction, either due to dispersion from the implant site or through degradation, investigators have found that it is necessary to immobilize the protein in some manner while retaining its bioactivity. Therefore, preclinical and clinical research has focused on a suitable delivery system or carrier for BMP. Three main types of materials have received attention: biologic materials, including collagen, fibrin glue, active and inactive demineralized freezedried bone allograft (DFDBA), and residual bone following extraction of BMPs with 4M guanidine; inorganic materials like hydroxyapatite and coral derivatives; and synthetic polymers like polylactic acid (PLA) and polylacticpolyglycolic acid copolymers (poly-D,L-lactide-coglycolide, PLG). The advantages of synthetic polymers compared to biologic materials are biocompatibility, minimal immunogenicity, biodegradability, and the fact that they can be manufactured with high reproducibility (Miller et al., 1977; Agrawal et al., 1995; Duggirala et al., 1996). Due to good properties of monoolein and chitosan gels, the authors decided to use these materials as carriers for rhBMP-2 in Wistar rat mandibles, using the decortication technique.

\footnotetext{
"Faculty of Dentistry, University of São Paulo, Ribeirão Preto, São Paulo, Brazil.

*** Faculty of Medicine, University of São Paulo, Ribeirão Preto, São Paulo, Brazil.
} 
ISSA, J. P. M.; TIOSSI, R., WATANABE, P. C. A.; SIÉSSERE, S.; REGALO, S. C. H. ; LOPES, R. A.; Di MATTEO, M. A. S.; IYOMASA, M. M. \& DEFINO, H. L. A.Newly formed bone in mandible decortication experimental model using rhBMP-2 evaluated by densitometric study. Int. J. Morphol., 26(1):83-88, 2008.

Bone densitometry is a commonly used procedure in general medicine to measure the mineral content of the bone.

The method helps in establishing an early diagnosis of metabolic diseases of the bone (especially osteoporosis), which decreases the incidence of pathological fractures in a high degree. Recent studies have shown that significant correlation can be found between the optical densitometric evaluations of the jaws and the densitometric figures of other bones of the skeleton (spine, hip). These results point out the possible role of the dentist in the early diagnosis of osteoporosis. The recent methods in general medicine are based on the measurement of photon and X-ray absorption followed by computerized analysis (single photon absorptiometry, single energy $\mathrm{x}$ ray absorptiometry, dual photon absorptiometry, dual energy X-ray absorptiometry). Besides the previously mentioned techniques ultrasound attenuation detection (quantitative ultrasound) and computed tomographic approaches are also widely spread. Methods utilizing the developed panoramic X-ray films are also being used for densitometric evaluations. The results given by these measurements seem to be promising as a unique detection of the early signs of osteoporosis (Koppany et al., 2007).

Dual energy X-ray absorptiometry (DEXA) is a technique that enables fast, noninvasive, and highly precise measurement of bone mineral density (BMD) (Devlin et al., 1998). In daily clinical practice, DEXA is the most useful method for BMD assessment in the vertebrae, femoral neck, forearms and mandible (von Wowern, 2001). This technique was introduced in 1987 (Hildebolt, 1997). Its operation is based on the principle that bone and soft tissue exhibit different properties of attenuation as a function of photon energy. Therefore, DEXA uses an xray source to produce a beam of discrete energies that is attenuated as it travels through the patient (Hildebolt; Devlin et al.; Horner \& Devlin, 1998b; Choel et al., 2003). The precision of DEXA in vivo, is $2 \%$ to $3 \%$, and the accuracy is $6 \%$ to $7 \%$ (von Wowern). The radiation dose is low enough to allow bone mineral content (BMC) and BMD measurements in different skeletal sites and in longitudinal studies (Hildebolt; von Wowern). Computerized analysis of the emergent beam produces separate attenuation profiles for bone and soft tissue structures, and from this the BMD is automatically calculated (Komarnyckyj \& London, 1998).

The aim of this study was to evaluate the newly formed bone, comparing two different carriers for rhBMP2 , using the decortication and nondecorticatication surgical technique in Wistar rat mandibles, evaluated by optical densitometry method.

\section{MATERIAL AND METHOD}

This randomized study followed all the requirements of the Ethics Committee on the Use of Animals in Experimentation at the University of São Paulo, Brazil. A pilot study ( $\mathrm{n}=8$ rats) was initially carried out to verify whether this technique in the mandible of rats would be feasible, the rhBMP-2 dose, and the period of time until the sacrifice. All animals were watched clinically all days after the surgery until the sacrifice.

Substances. The recombinant human bone morphogenetic protein, type 2 (rhBMP-2) used in this study was obtained at Theodor-Boveri-Institut für Biowissenschaften, Am Hubland, Würzburg, Germany. Monoolein (Myverol 18-99, 98.1\% monoglycerides, Naarden, The Netherlands) gel in cubic phase was prepared in a 7:3 (monoolein:water) proportion as described previously. Briefly, monoolein was weighed, heated to $45^{\circ} \mathrm{C}$ and mixed with water at the same temperature. After resting for some time the mixture became a transparent and viscous mass. An aqueous rhBMP-2 solution $(1 \mathrm{mg} / \mathrm{mL})$ was then added and the mixture homogenized. Chitosan (Hidagem HCMF, Cognis, Spain) gel was prepared by dispersion of $8.3 \mathrm{mg}$ of chitosan in $1.0 \mathrm{~mL}$ of rhBMP-2 aqueous solution and acidification with acetic acid (1.0\%).

Animals. Fifty six male Wistar rats $(n=56)$ weighing around $300 \mathrm{~g}$ were selected, allowed to acclimatize for one week prior to surgery and divided equally $(n=28)$ into two groups, considering the periods until the sacrifice, three and six weeks. Thus, each one of these groups was randomly divided in four groups with seven animals each $(n=7)$, considering the applied treatment. The animals were fed with commercial rat chow and had access to food and water ad libitum. The decortication of the bone was created in the middle region of the right hemi-mandible body $(5 \times 5 \mathrm{~mm})$ in each animal. Groups and materials applied: 5mg rhBMP- $2+$ monoolein gel (Group I, decortication, 3 weeks), 5mg rhBMP-2 + monoolein gel (Group II, nondecortication, 3 weeks), $5 \mathrm{mg}$ rhBMP-2 + chitosan gel (Group III, decortication, 3 weeks), $5 \mathrm{mg}$ rhBMP-2 + chitosan gel (Group IV, nondecortication, 3 weeks), 5mg rhBMP-2 + monoolein gel (Group V, decortication, 6 weeks), 5mg rhBMP-2 + monoolein gel (Group VI, nondecortication, 6 weeks), 5mg rhBMP-2 + chitosan gel (Group VII, decortication, 6 weeks), 5mg rhBMP-2 + chitosan gel (Group VIII, nondecortication, 6 weeks). The surgical area was recovered by adjacent muscular tissues, being possible to maintain these applied substances in the bone defect, especially for the group I.

Surgical procedure. The rats were anaesthetized with a 
ISSA, J. P. M.; TIOSSI, R., WATANABE, P. C. A.; SIÉSSERE, S.; REGALO, S. C. H. ; LOPES, R. A.; Di MATTEO, M. A. S.; IYOMASA, M. M. \& DEFINO, H. L. A.Newly formed bone in mandible decortication experimental model using rhBMP-2 evaluated by densitometric study. Int. J. Morphol., 26(1):83-88, 2008.

standard anesthetic cocktail consisting of ketamine hydrochloride $(60 \mathrm{mg} / \mathrm{Kg})$ and xylazine $(5 \mathrm{mg} / \mathrm{Kg})$, administered intraperitoneally. Surgery was performed using aseptic techniques. A linear incision was made through the skin, subcutaneous tissues and masseter muscle, parallel to the inferior border of the mandible. The mandible buccal surface was exposed and the bone decortication defect was created in the middle region of the mandible body maintaining the periosteum layer. In the groups without decortication process, just the surgical access was made in this region and materials insertion, without bone cutting. The osteotomy in the decortication groups was performed using a manual instrument, under abundant irrigation with saline solution $(0.9 \%)$.

Sacrifice and animal perfusion. After three and six weeks respectively, animals were anaesthetized with urethane $37.5 \%(1.5 \mathrm{~g} / \mathrm{Kg})$ and submitted to perfusion. The procedure involved an intracardiac infusion of saline solution $(100 \mathrm{~mL})$ followed by $10 \%$ formalin and paraformaldehyde $4 \%$ in $0.2 \mathrm{M}$ phosphate buffer $(100 \mathrm{~mL})$. The right hemi-mandibles were removed for histological processing.

Densitometric study. The right hemimandibles of both groups were separated from the skull and the soft tissues were carefully removed. These hemimandibles were placed over extrabuccal radiographic film (T-MAT, Kodak, Kodak do Brasil Ltda., São José dos Campos/SP, Brasil). The X-Ray apparel (Weber, type 11R, Weber Company, USA) was perpendicularly placed in relation to the film, $40 \mathrm{~cm}$ of focus-film distance, and a single radiographic exposition was performed with $10 \mathrm{~mA}$, $64.5 \mathrm{kVp}$ and 0.16 seconds. All these factors were monitorated by apparel/system Victodreen NERO 6000B (Non-Invasive Evaluator Radiation Outputs, Modelo 6000B, Victoreen Inc-USA).

The radiographic image obtained was digitalized in a professional scanner (Expression 636, EPSON Ltda, USA) and cut accord to interested regions using the Adobe Photoshop 7.0.1 program (Adobe, Adobe System Corporation Inc., USA). The resulted images containing the newly formed bone were submitted to optical densitometry analysis using the Sidex program (S3DX, Sidex Company, New York, USA). For this analysis, it was traced two diagonal lines beginning from the vertices of a regular square, placed in the newly formed bone area. On each line it was measured 100 dots for optical density. The total value for optical density in mandible was the mean of the values found in these two lines.

Statistical analysis. Data analysis was performed using GLM ANOVA with Tukey test and 95\% of significance level.

\section{RESULTS}

Data of this study showed greatest values for optical density in the groups that the rhBMP-2 was combined with the carriers, monoolein and chitosan gels, doing the decortication surgery in the mandible, especially at 6 weeks. Thus, it was found statistical difference according to surgical technique, decortication and nondecortication $(\mathrm{p}<0.05)$, but it was not found statistical difference according to time factor $(\mathrm{p}>0.05)$. It was not found statistical difference between the carriers used, monoolein and chitosan gel ( $p>0.05)$.

Table I. Means (pixels) and standard deviations of the groups after densitometric study.

\begin{tabular}{lrc} 
Groups & Mean & SD \\
\hline I & 142.43 & 10.12 \\
II & 83.24 & 6.79 \\
III & 138.29 & 8.92 \\
IV & 94.76 & 7.14 \\
V & 157.94 & 10.04 \\
VI & 95.06 & 5.23 \\
VII & 166.22 & 9.07 \\
VIII & 98.14 & 6.2
\end{tabular}

\section{DISCUSSION}

The purpose of this study was to evaluate the newly formed bone, comparing two different carriers for rhBMP2, using the decortication and nondecorticatication surgical technique in Wistar rat mandibles, evaluated by optical densitometry method.

BMPs combined with different carrier materials have been shown to heal experimental bone defects in many studies (Hollinger et al.; Tuominen et al.; Kokubo et al.).

Studies in medical and dentistry area are concentrated in the investigation of the new bone formation dynamic and in the mechanical characteristics of the newly formed bone (Meyer et al., 2001; Jihua et al., 2002; Novaes et al., 2004). In studies that it was used odontologic X-ray apparel (Mansini, 2000; Landin et al., 2002; Simões et al., 2003; Looder et al., 2004), there is discussions about the possible variations in the exposition time, Kvp and Ma in different radiographic registers. These variations can affect the final results of the optical density.

The radiographic film (T-MAT, Kodak) and apparel Weber, type 11R, USA used in this work, permitted to obtain 
images of the fifty six mandibles analyzed through a single radiographic exposition, removing these variables.

The Sidexis program for bone densitometry provides a numeric analysis of each dot contained in a linear trace made in a radiography using the program. These representative numbers of bone density established by the program were analyzed after a statistical study. The mean values obtained showed that there was found statistical difference according to surgical technique, decortication and nondecortication, but it was not found statistical difference according to time factor. It was not found statistical difference between the carriers used, monoolein and chitosan gel. The decortication was able to expose the bone marrow and speed up the bone healing process (Conti et al., 2006). Biological factors related to these phenomena are not totally identified. It is believed that mesenchymal cells are able to differentiated into osteoblasts and chondroblasts, stimulated by local factors like bone morphogenetic proteins, platelet-derived growth factor, interleukin, fibroblast growth factor, insulin-like growth factor, granulocyte-colony-stimulating factors and granulocyte-macrophage colony stimulating factors (Vaccaro et al., 2002).

Regional differences in jaw anatomy and bone structure may explain some of the variations in the success rate of clinical therapy in the maxilla (Devlin et al.). Surveys (Higuchi et al., 1995; Devlin et al.; Choel et al.) have shown that surgical procedures in maxilla has a significantly higher clinical failure rate than in the mandible, and regional differences in maxillary BMD may be partly responsible. Devlin et al. found that the posterior maxilla had the lowest BMD. The lack of initial stability in poor-quality bone results in lower success rates for dental implants, which vary from $50 \%$ to $94 \%$ (Martinez et al., 2001). This type of bone is often present in the posterior area of the jaws (Martinez et al.; Nkenke et al., 2002).

We used the Sidex software to measure BMD. Numerous investigators (Devlin et al.; Horner \& Devlin, 1998a; Horner et al., 1996) have assessed BMD in edentulous regions of the jaws. Corten et al. (1993) and Horner et al. used a conventional skeletal DEXA scanner to obtain BMD and BMC measurements of the mandible and the maxilla (Hildebolt ; Devlin et al.). Those investigators demonstrated a significant correlation between the BMD of the mandible and that of the lumbar spine, femoral neck, and forearm (Horner \& Devlin, 1998b). Devlin et al. assessed the BMD of 3 regions of the maxilla and 1 site in the mandibular body in edentulous subjects. Their study was the first investigation to perform DEXA measurement of the maxilla and showed that BMD in the posterior maxilla was the lowest of all jaw BMD measurements.

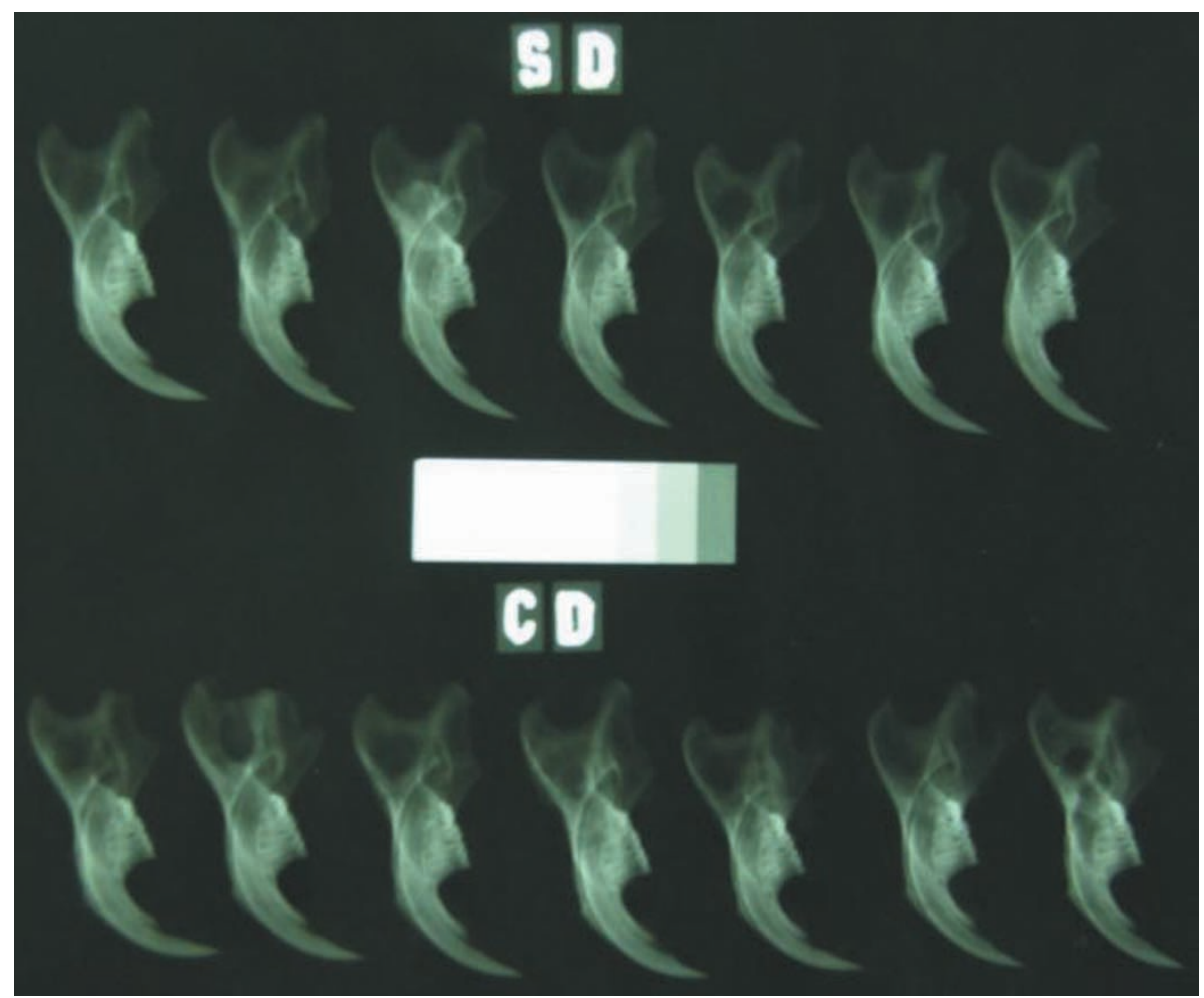

Fig. 1. Photomicrography showing the radiographic method used in this study. SD- Without decortication; CD- With decortication.
It was possible to conclude that the decortication surgical technique was able to optimize the osteoinduction properties of the rhBMP-2, independently of the material carrier used, especially at 6 weeks, but these periods of time, 3 and 6 weeks, did not present difference in relation to the new bone formation, according to this radiographic densitometry study.

Acknowledgements: We are grateful to FAEPA (HC-FMRP) for financial support. 
ISSA, J. P. M.; TIOSSI, R., WATANABE, P. C. A.; SIÉSSERE, S.; REGALO, S. C. H. ; LOPES, R. A.; Di MATTEO, M. A. S.; IYOMASA, M. M. \& DEFINO, H. L. A.Newly formed bone in mandible decortication experimental model using rhBMP-2 evaluated by densitometric study. Int. J. Morphol., 26(1):83-88, 2008.

ISSA, J. P. M.; TIOSSI, R., WATANABE, P. C. A.; SIÉSSERE, S.; REGALO, S. C. H. ; LOPES, R. A.; Di MATTEO, M. A. S.; IYOMASA, M. M. \& DEFINO, H. L. A. Tejido óseo neoformado en el modelo experimental de la retirada de la cortical ósea mandibular utilizando rhBMP-2. Int. J. Morphol., 26(1):83-88, 2008.

RESUMEN: El propósito de este estudio es evaluar la neoformación ósea con la densitometría radiográfica, comparando dos transportadores diferentes para el rhBMP-2, mediante la técnica quirúrgica con o sin la retirada previa de la cortical ósea, en mandíbulas de ratas Wistar. Fueron utilizados 56 animales, de acuerdo con el tratamiento específico, sacrificados después de 3 y 6 semanas. La densitometría radiográfica permitió concluir que la técnica quirúrgica de retirada de la cortical puede optimizar las características osteoinductoras del rhBMP-2, independientemente del transportador usado y del tiempo transcurrido.

PALABRAS CLAVE: Radiografía; Densitometría; Mandíbula; rhBMP-2; Hueso.

\section{REFERENCES}

Agrawal, C. M.; Best, J.; Heckman, J. D. \& Boyan, B. D. Protein release kinetics of a biodegradable implant for fracture non-unions. Biomaterials., 16:1255-60, 1995.

Cheng, H.; Jiang, W.; Phillips, F. M.; Haydon, R. C.; Peng, Y.; Zhou, L.; Luu, H. H.; An, N.; Breyer, B.; Vanichakarn, P.; Szatkowski, J. P.; Park, J. Y. \& He, T.C. Osteogenic activity of the fourteen types of human bone morphogenetic proteins (BMPs). J. Bone. Joint. Surg. (Am)., 85:1544-52, 2003.

Choel, L.; Duboeuf, F.; Bourgeois, D.; Briguet, A. \& Lissac, M. Trabecular alveolar bone in the human mandible: a dual-energy x-ray absorptiometry study. Oral. Surg. Oral. Med. Oral. Pathol. Oral. Radiol. Endod., 95:364-70, 2003.

Conti, O. J.; Pastorello, M.T. \& Defino, H. L. A. Estudo experimental da decorticação óssea na integração dos enxertos na coluna vertebral. Acta. Ortop. Bras., 14: 67-71, 2006.

Cook, S. D. Preclinical and clinical evaluation of osteogenic protein-1 (BMP-7) in bony sites. Orthopaedics., 22:669$71,1999$.

Corten, F. G.; van't Hof, M. A.; Buijs, W. C.; Hoppenbrouwers, P.; Kalk, W. \& Corstens, F. H. Measurement of mandibular bone density ex vivo and in vivo by dual-energy x-ray absorptiometry. Arch. Oral. Biol., 38:215-9, 1993.

Devlin, H.; Horner, K. \& Ledgerton, D. A comparison of maxillary and mandibular bone mineral densities. $J$. Prosthet. Dent., 79:323-7, 1998.

Duggirala, S. S.; Mehta, R. C. \& DeLuca, P. P. Interaction of recombinant human bone morphogenetic protein-2 with poly (d,1 lactide- co-glycolide) microspheres. Pharm. Dev. Tech., 181:11-9, 1996.

Gao, T. J.; Lindholm, T. S.; Kommonen, B.; Ragni, P.;
Paronzini, A.; Lindholm, T. C.; Jalovaara, P. \& Uris, M. $\mathrm{R}$. The use of a coral composite implant containing bone morphogenetic protein to repair a segmental tibial defect in sheep. Int. Orthop., 21:194-200, 1997.

Govender, S.; Csimma, C.; Genant, H. K. \& ValentinOpran, A. Recombinant human bone morphogenetic protein- 2 for treatment of open tibial fractures: a prospective, controlled, randomized study of four hundred and fifty patients. J. Bone. Joint. Surg. (Am)., 84:2123-34, 2002.

Higuchi, K. W.; Folmer, T. \& Kultje, C. Implant survival rates in partially edentulous patients: a 3-year prospective multicenter study. J. Oral. Maxillofac. Surg., 53:264-8, 1995.

Hildebolt, C. F. Osteoporosis and oral bone loss. Dentomaxillofac. Radiol., 26:3-15, 1997.

Hollinger, J. O.; Schmitt, J. M.; Buck, D. C.; Shannon, R.; Joh, S. P.; Zegzula, H. D. \& Wozney, J. Recombinant human bone morphogenetic protein-2 and collagen for bone regeneration. J. Biomed. Mater. Res., 43:356-64, 1998.

Horner, K. \& Devlin, H. The relationship between mandibular bone mineral density and panoramic radiographic measurements. J. Dent., 26:337-43, 1998a.

Horner, K. \& Devlin, H. The relationships between two indices of mandibular bone quality and bone mineral density measured by dual energy X-ray absorptiometry. Dentomaxillofac. Radiol., 27:17-21, 1998b.

Horner, K.; Devlin, H.; Alsop, C. W.; Hodgkinson, I. M. \& Adams, J. E. Mandibular bone mineral density as a predictor of skeletal osteoporosis. Br. J. Radiol., 69:101925,1996 . 
ISSA, J. P. M.; TIOSSI, R., WATANABE, P. C. A.; SIÉSSERE, S.; REGALO, S. C. H. ; LOPES, R. A.; Di MATTEO, M. A. S.; IYOMASA, M. M. \& DEFINO, H. L. A.Newly formed bone in mandible decortication experimental model using rhBMP-2 evaluated by densitometric study. Int. J. Morphol., 26(1):83-88, 2008.

Jihua, L.; Dazhang, W.; Zhenglong, T. \& Zhanwei, G. Biochimical properties of regenerated bone by mandibular distraction osteogenesis. Clin. J. Traumatol., 2:67-70, 2002.

Jortikka, L.; Marttinen, A.\& Lindholm, T. S. Partially purified reindeer (Rangifer Tarandus) bone morphogenetic protein has a high bone-forming activity compared with some other artiodactylis. Clin. Orthop., 297:33-7, 1993a.

Jortikka, L.; Marttinen, A. \& Lindholm, T. S. Purification of monocomponent bovine morphogenetic protein in a watersoluble form. Ann. Chir. Gyn., 82:25-30, 1993 b.

Kokubo, S.; Fujimoto, R. \& Yokota, S. Bone regeneration by recombinant human bone morphogenetic protein-2 and a novel biodegradable carrier in a rabbit ulnar defect model. Biomaterials, 24:1643-51, 2003.

Komarnyckyj, O. G. \& London, R. M. Osteotome single-stage dental implant placement with and without sinus elevation: a clinical report. Int. J. Oral. Maxillofac. Implants., 13:799804, 1998.

Koppany, F.; Joob-Fancsaly, A. \& Szabo, G. Possible methods for evaluating bone density in the maxillofacial region. Fogorv. Sz., 100:77-81, 2007.

Landin, K. T.; Junqueira, J. C. \& Rocha, R. F. Influence of the sinvastatin on bone regeneration of mandibles of rats. Rev. Fac. Odontol. São José dos Campos., 5:78-83, 2002.

Looder, M.C.; Lems, W. F.; Ader, H. J.; Marthinsen, A. E.; van Coeverden, S. C.; Lips, P.; Netelenbos, J. C.; Dijkmans, B. A. \& Roos, J. C. Reproducibility of bone mineral density measurement in daily practice. Ann. Rheum. Dis., 63(3):285-9, 2004.

Mansini, R. Avaliação in vitro da densidade óssea de mandíbulas edêntulas por meio do sistema de dupla emissão de raios $\mathrm{X}(\mathrm{DXA})$ e pela digitalização de radiografias intrabucais com filme Ultra-Speed "D". Revista da Pósgraduação da Faculdade de Odontologia da Universidade de São Paulo, 7:205-13, 2000.

Martinez, H.; Davarpanah, M.; Missika, P.; Celletti, R. \& Lazzara, R. Optimal implant stabilization in low density bone. Clin. Oral. Implants. Res., 12:423-32, 2001.

Matsuo, T.; Sugita, T.; Kubo, T.; Yasunaga, Y.; Ochi, M. \& Murakami, T. Injectable magnetic liposomes as a novel carrier of recombinant human BMP-2 for bone formation in a rat bone-defect model. J. Biomed. Mater. Res., 66A:747- 54, 2003.
Meyer, U.; Terodde, M.; Joos, U. \& Wiesmann, H. P. Mechanical stimulation of osteoblasts in cell culture. Mund. Kiefer. Gesichtschir., 5:166-72, 2001.

Miller, R. A.; Brady, J. M. \& Cutright, D. E. Degradation rates of oral resorbable implants (polylactates and polyglycolates): rate modification with changes in PLA/ PGA copolymer ratios. J. Biomed. Mater. Res., 11:711-9, 1977.

Nkenke, E.; Kloss, F.; Wiltfang, J.; Schultze-Mosgau, S.; Radespiel-Tröger, M.; Loos, K. \& Neukam, F. W. Histomorphometric and fluorescence microscopic analysis of bone remodelling after installation of implants using an osteotome technique. Clin. Oral. Implants. Res., 13(6): 595-602, 2002.

Novaes, A. B.; Papalexiou, V.; Grisi, M. F.; Souza, S. S.; Taba, M. \& Kajiwara, J. K. Influence of implant microstuture on the osseointegration of imediate implants placed in periodontally infected sites. Clin. Oral. Implant. Res., 1: 34-43, 2004.

Simões, F. X. P. C.; Araújo, T. M. \& Bittencourt, M. A. V. Avaliação da manutenção óssea na sutura palatina mediana, após expansão rápida da maxila, por meio da imagem digitalizada. Rev. Dental. Press. Ortodon. Ortop. Facial., 8:59-67, 2003.

Tuominen, T.; Jämsä, T.; Tuukkanen, J.; Nieminen, P.; Lindholm, T. C.; Lindholm, T. S. \& Jalovaara, P. Native bovine bone morphogenetic protein improves the potential of biocoral to heal segmental canine ulnar defects. Int. Orthop., 24:289-94, 2000.

Vaccaro, A. R.; Chiba, K.; Heller, J. G.; Patel, T. C.; Thalgott, J.S.; Truumees, E.; Fischgrund, J. S., Craig, M. R.; Berta, S. C.; Wang, J. C. \& North American Spine Society for Contemporary Concepts in Spine Care. Bone grafting alternatives in spinal surgery. Spine J., 2(3):206-15, 2002.

von Wowern, N. General and oral aspects of osteoporosis: a review. Clin. Oral. Investig., 5:71-82, 2001.

Wozney, J.M. Overview of bone morphogenetic proteins. Spine, 27:S2-8, 2002.

\section{Correspondence to:}

João Paulo Mardegan Issa

Faculdade de Odontologia de Ribeirão Preto - USP

Departamento de Morfologia, Estomatologia e Fisiologia

CEP: 14040-904, Monte Alegre

Av. Café S/N, Ribeirão Preto, SP

BRAZIL

Received: 10-10-2007

E-mail: jpmissa@forp.usp.br 